\title{
Retractation note: Historical development of IEQ in Danish dwellings - has energy efficiency requirements inhibited positive IEQ developments?
}

Guest editors: S.I Tanabe, H. Zhang, J. Kurnitski, M.C. Gameiro da Silva, I. Nastase, P. Wargocki, G. Cao, L. Mazzarela and C. Inard

Original article: E3S Web of Conferences 111, 02055 (2019), https://doi.org/10.1051/e3sconf/201911102055

This article is an accidental publication. It was accepted by the Guest Editors in charge of the peer-review process without the authors' final consent.

The Guest Editors have given their approval for this decision. 